\title{
FORMATION OF COMPONENTS OF ECONOMIC DEVELOPMENT OF THE COUNTRY AND ITS REGIONS WITHIN THE FRAMEWORK OF DECENTRALIZATION
}

\author{
Olga Gornyak', Lidiya Voloshchuk², Ganna Prokofieva
}

\begin{abstract}
The reform of economics' decentralization caused the need to interpret differently the role and importance of regions in the structure of the economic system. The regional economy, along with the national economy, becomes an equal participant in economic activity both on the domestic and foreign markets. The purpose of the article is to study the peculiarities and formation of components of economic development of Ukraine and its regions in the process of decentralization of economic power, revealing its tendencies and contradictions, as well as ways of their overcoming. Methodology. The article uses general scientific and special methods: generalization, systematization, economic and statistical analysis, and modelling. This allowed us to study the peculiarities of the economic development of Ukraine and its regions in the process of decentralization, to identify its tendencies and contradictions, as well as to justify ways to overcome them. Results. The analysis of components of economic development in a regional context provides an opportunity to identify the main trends and prospects for the economic development of the country. Among the components of economic development, the main role is performed by the economic component since it determines the main trends of the economy of the country and regions. There are offered qualitative and quantitative components' parameters that provide sustainable economic development in conditions of uncertainty. Practical meaning. The implementation of these results will overcome the disproportion of regional economic development in Ukraine. Equalization of the regional economic development involves the creation of a favourable investment environment in the regions, as the current trends of regional development lead to the fact that regions and other territorial entities become independent gamblers near the state in the global economic space. Value/originality. The article analyses the factors and consequences of the decentralization of the economy. Unlike the existing approaches, this makes it possible to more systematically present the results of economic development at the present stage.
\end{abstract}

Key words: economic development, regional economic development, national economy, regional economy, region, components of economic development, decentralization of economic power.

JEL Classification: H70, R10, R50, R12, R13

\section{Introduction}

The development of national and regional economies is characterized by Ukraine's peculiarities and is a consequence of the previous stages and specific aspects of the present one. The present stage of the development of the economy is marked, first of all, by the processes of decentralization of economic power. This involves a change in the system of state administration, financing, the economy in the social

\footnotetext{
Corresponding author:

${ }^{1}$ Odessa I.I. Mechnikov National University, Ukraine.

E-mail: olga.gornyak.et@gmail.com

ORCID: https://orcid.org/0000-0002-4954-8101

${ }^{2}$ Odesa National Polytechnic University, Ukraine.

E-mail: 1.a.voloschuk@gmail.com

ORCID: http://orcid.org/0000-0002-9692-7438

${ }^{3}$ Odessa I.I. Mechnikov National University, Ukraine.

E-mail: ganett@ukr.net

ORCID: https://orcid.org/0000-0002-0866-6638
}

sphere, as well as shifts in the structure of the national and regional economy, the growth of the role of regions and territories, the provision of self-development mechanisms and, eventually, the improvement the quality of life and well-being in Ukraine. In the last three decades, the regions have started to differ significantly from each other in terms of economic development, and the national economy is characterized by unevenness, disproportionality, and bifurcation of economic development (Prokofieva, 2018; Filippenko, 
2006). Taking into account the contradictory effect of economic development factors at different levels, it can be noted that such characteristics have been formed over a sufficiently long period, which complicates the provision of prerequisites for sustainable economic development at the current stage.

In recent years, the reduction of these differences between regions, bringing them closer in terms of the level of economic development, has become much more difficult, while the war is carried in the eastern regions of Ukraine and the Crimea is occupied by Russia. But, considering the growing role of the regional economy, there have already been formed objective conditions for more comprehensive development of the national economy and regions. In this process, besides objective processes, the important role is played by the state, its scientifically based policy. In Ukraine, there were adopted the Laws on decentralization of power and granting of independence to regions, the realization of which will eventually ensure harmonization of economic development of regions (Voluntary association of territorial communities, 2015). The realization of decentralization principles can be confirmed by such results as the formation of united territorial communities (hereinafter named as UTC): in 2015, there were created 159 communities, and in $2018-874$ of them. The legal capacity of the communities, through which the decentralization is being implemented, according to analysts, is related to their capacity for "strategic development based on the use of all available resources" (Zhalilo et al., 2018). In view of the fact that only 3.9 thousand of 10.9 thousand communities were united, that is $60.4 \%$ of the communities have not been united yet, so the attention should be paid to the further development and formation of capable communities, to study the causes and possibilities of decentralization potential's realization. The processes of creation of UTSs should be intensified by effective interaction between state authorities and local self-government bodies. In addition, the role of regional government should also increase steadily.

A large number of works by leading Ukrainian and foreign economists are devoted to the issues of economic development of the national and regional economy. Among them there should be mentioned, first of all, such economists as A. S. Galchynskyi, V. Haiets, D. Geld, D. Golblat, Ya. A. Zhalilo, D. M. Maier, E. MacGrew, D. Rauch, J. Perraton, T. Protsenko, V. F. Semenov, O. P. Tyshchenko, A. Filippenko and others. Their works provide theoretical concepts and methodological principles for the analysis of economic development both in the developed and in the transformational economies. But there is a need for further analysis of the peculiarities of the economic development of the transformational economy in a context of decentralization.

\section{Components of economic development of the national and regional economy}

The process of decentralization of economic power is based on an objective analysis of the current state of development of the national and regional economy of Ukraine. Regions of Ukraine differ in terms of natural conditions, social and economic development, as well as by ethnolinguistic, historical, psychological, religious, and cultural characteristics. Depending on a particular feature, Ukraine's economy is divided into regions. Thus, according to historical and economic characteristics, there are defined old-industrial, agro-industrial, and transportrecreational regions; according to the economicgeographical position, there are distinguished Seaside, Prydniprovsky (near Dnipro River), Border-Mountain and Plain regions (Semenov, Protsenko, 2009).

This classification is not yet recognized by the official statistics because statistical data is grouped based on the division of the Ukrainian economy into the regions, which is obsolete and does not reflect the current trends in the region's economy. In modern conditions, an important role is played by the spatial factor, which is the result of the interaction of economic agents located in the territory. The economic development of the national economy and regions under the influence of the spatial factor is ensured not through a competitive but through cumulative growth. Agglomeration effects, effective urban structures, favourable investment climate in the region, level of regional infrastructure development and others act as spatial factors (Held et al., 2003).

The process of cumulative growth involves the action of all factors that determine the peculiarities of regional development. The results of their actions can be both positive and negative. In determining the level of cumulative growth, it should take into account the impact on productivity in the region of the economy from the scale of production, technological progress, the structure of production, the favourability to innovations in the leading industries of the region. Cumulative growth supposes self-development of the region through the use of the region's competitive advantages, internal factors, and opportunities for interaction with other regions (Maier et al., 2003). Using this approach, the national economy evolves itself in the process and via interaction between regions' economies, eliminating the competitive allocation of resources between regions, in other words, the philosophy of the organization of national and regional economies is changing (Zhalilo et al., 2018). Economic development is a complex multilevel process, the study of which involves an analysis of its essence, structure, factors, and consequences. The structure of economic development can be represented as an organic combination of its components: geographical, demographic, economic, financial, social, environmental, and institutional. Their characteristics are presented in Table 1. 
Table 1

Components of economic development of the national and regional economy and their main characteristics

\begin{tabular}{|c|c|c|c|c|c|}
\hline $\begin{array}{l}\text { Demographic } \\
\text { and geographic }\end{array}$ & Economic & Financial & Social & Environmental & Institutional \\
\hline $\begin{array}{l}\text { 1. The size of the } \\
\text { territory } \\
\text { 2. Population } \\
\text { 3. Indexes of } \\
\text { mortality and fertility } \\
\text { 4. The number of } \\
\text { the working-age } \\
\text { population } \\
\text { 5. Population density } \\
\text { 6. Ethno-cultural } \\
\text { features } \\
\text { 7. Level of } \\
\text { urbanization }\end{array}$ & $\begin{array}{l}\text { 1. Gross domestic product } \\
\text { and its dynamics } \\
\text { 2. The share of GRP in } \\
\text { GDP of the country } \\
\text { 3. Investment climate and } \\
\text { dynamics of investments } \\
\text { 4. Sectoral structure of } \\
\text { national and regional } \\
\text { economy and trends of its } \\
\text { development } \\
\text { 5. Foreign economic } \\
\text { activity and dynamics of } \\
\text { direct foreign investments } \\
\text { 6. National and regional } \\
\text { markets, their structure } \\
\text { and capacity }\end{array}$ & $\begin{array}{l}\text { 1. Financial resources } \\
\text { of development and } \\
\text { their dynamics } \\
\text { 2. Structure of } \\
\text { financial resources } \\
\text { 3. The economic } \\
\text { activity's crediting of } \\
\text { financial enterprises } \\
\text { 4. Financial resources } \\
\text { of insurance } \\
\text { companies } \\
\text { 5. Financial resources } \\
\text { of pension funds } \\
6 . \text { Household } \\
\text { finances, their } \\
\text { structure and } \\
\text { dynamics }\end{array}$ & $\begin{array}{l}\text { 1. The level of life } \\
\text { and welfare of the } \\
\text { population } \\
\text { 2. Structure and } \\
\text { dynamics of incomes } \\
\text { and expenses } \\
\text { 3. Poverty level } \\
\text { 4. Social problems of } \\
\text { development of the } \\
\text { country and regions } \\
\text { 5. Level of } \\
\text { employment and } \\
\text { unemployment } \\
\text { 6. Human } \\
\text { Development Index }\end{array}$ & $\begin{array}{l}\text { 1. The ecological } \\
\text { stability of the } \\
\text { country and the } \\
\text { region } \\
2 \text {. Average life } \\
\text { expectancy } \\
\text { 3. Pollution of } \\
\text { territory, water and } \\
\text { air } \\
\text { 4. Urbanization } \\
\text { processes and their } \\
\text { consequences } \\
\text { 5. Structure of } \\
\text { production in } \\
\text { the context of } \\
\text { the ecological } \\
\text { component }\end{array}$ & $\begin{array}{l}\text { 1. Institutions } \\
\text { and bodies of } \\
\text { economic power } \\
\text { 2. Institutions } \\
\text { of real } \\
\text { infrastructure } \\
\text { 3. Institutions } \\
\text { of financial } \\
\text { infrastructure } \\
\text { 4. Public } \\
\text { Institutions } \\
\text { 5. Forms of } \\
\text { organization } \\
\text { of national } \\
\text { and regional } \\
\text { economies }\end{array}$ \\
\hline
\end{tabular}

Source: developed by the authors

The analysis of the level of economic development in Ukraine involves solving the problems of uneven distribution of incomes between regions, the difference in the rates of growth in production, unemployment rates, and social indexes. The policy, economic and social history of Ukraine, and the complexities of systemic changes must also be taken into account. There are many variants of classification of Ukrainian regions in the literature in terms of the level of social and economic development. These classifications are already included in the textbooks (Semenov, 2006; Semenov, Protsenko, 2009). Most researchers believe that all regions of Ukraine are represented by three groups: developed regions; regions with an average level of development; and regions with a low level of development, which, in their turn, are divided into backward and depressed.

According to the classification of the Institute of Reforms, in the group of developed regions of Ukraine, there are distinguished such regions with a high development level as Zaporizhzhia and Lviv regions ( $8 \%$ of the total number of regions), as well as regions with a very high level of social and economic development, namely: Dnipropetrovsk, Donetsk (before the beginning of hostilities in 2014) and Kharkiv regions $(12 \%)$. Thus, the group of developed regions occupies $20 \%$ of the total number of regions. The group of regions with an average level of development (12\%) includes Kyiv and Odesa regions, and Crimea (prior to the annexation). Regions with very low development (40\%) include such regions as Volyn, Zhytomyr, Zakarpattia, Kirovohrad, Rivne, Ternopil, Kherson, Khmelnytskyi, Chernihiv, and Chernivtsi. The low level of development (28\%) is typical for such regions as Vinnytsia, Ivano-Frankivsk, Luhansk, Poltava, Sumy, and Cherkasy (Semenov, Protsenko, 2009). This classification has certain disadvantages because the level of development of some areas is not accurately measured. For example, Poltava region belongs to a group with a low level of development, although, according to all social and economic indexes, it should be included in regions with an average level of development.

\section{Geographical and demographic component of regional economic development of Ukraine}

The regions of Ukraine differ in size and population number, which forms the natural basis for diversity and uneven social and economic development. Speaking about the territory size, the largest variance were between Odesa (33.3 thousand square kilometres) and Chernivtsi ( 8.1 thousand square kilometres), which is 4.1 times, and as to the population number -5.2 times between Donetsk region (4691.9 thousand people) and Chernivtsi region (911.8 thousand people) (Regions of Ukraine 2016, 2017), although the population of Donetsk region has significantly decreased over the past five years in connection with military actions, which led to a sharp decline in the population of the Donetsk region, both due to migration and as a result of hostilities.

The analysis of indexes of a geographical and demographic component of regional economic development of Ukraine shows the following results.

According to the size of the territories, the largest regions are Odesa (33.31), Dnipropetrovsk (31.914), Chernihiv (31.865), Kharkiv (31, 415), Zhytomyr (29.832), Poltava $(28,748)$, Kherson $(28,461)$, and Kyiv $(28,131)$. The smallest regions are Chernivtsi $(8,097)$, Zakarpattia $(12,777)$, Ternopil $(13,823)$ and Ivano-Frankivsk $(13,9)$. 
The calculation of the population growth rate indicates a reduction in its number in Vinnytsia, Zaporizhzhia, Kirovohrad, Luhansk, and Mykolaiv regions, with the largest decrease in 2016 and 2017. Also, the population's decline is observed in Kharkiv, Kherson, Poltava, Sumy, Khmelnytskyi, and Cherkasy regions. At the same time, the highest rates of population decline are typical for Chernihiv and Donetsk oblasts, although the reasons are different for these areas. Population declines in Ternopil region as well, the population decline rate in 2015 was $0.39 \%$, in 2016 it was already $0.61 \%$, and in 2017 $0.65 \%$. In Odesa region, the growth rate is negative in 2011, and during 2014-2017, while positive values are observed in 2012 (0.29\%) and in 2013 (0.05\%).

Other regions have more positive dynamics. According to the growth rate, the population growth had been increasing by 2015 in Volyn, Zakarpattia, Ivano-Frankivsk, and Chernivtsi regions. In the Rivne region, the growth rate becomes negative only in 2017 (-0.18\%). In Kyiv region and Kyiv city, population growth is increasing throughout the period under review. Herewith growth rates in Kyiv city are positive, however, declining from 2013 (Regions of Ukraine, 2016, 2017).

\section{Economic component of regional economic development of Ukraine}

Among the economic indexes that reflect the level of economic development in Ukraine, there are defined the dynamics of social and economic development, the state of the labour market, investment climate, and foreign economic relations. The main economic problems of Ukraine's development are the intensive aging of fixed assets. The share of equipment that has been operating for over 20 years is constantly increasing, which leads to an increase in repair costs. According to the calculations of economists, about 1 million workers are directly engaged in repairs in Ukraine, and, taking into account indirect works, 3 million workers, that is, every sixth employee of the manufacturing industry (Semenov, Protsenko, 2009). The problems of formation of the modern territorial structure of production, restrictions for the construction of new industrial enterprises in large cities, the use of opportunities for small and medium-sized cities, as well as urban-type settlements, where specialized enterprises, branches, and business units should be located, are remaining important issues. These problems can be successfully solved in the process of decentralization since local authorities receive wider powers and larger financial resources.

The dynamics of social and economic development is fundamentally ensured by industries that manufacture products mainly for the domestic market. These are the building activity, machine construction, telecommunications, and food industry. Particularly the influence of these industries is displayed in the conditions of mutual trade bans of Ukraine and Russia. The export-oriented industries, such as the metals and chemical industries have also contributed significantly to the development dynamics, but during recent years, the situation has changed both in the country and in world markets, and thus the positive impact of these industries has significantly decreased. Among the export-oriented industries that continue to increase their potential and positively influence on economic dynamics, there are singled out the agricultural industry, high-tech industries, and light industry.

The dynamics of industrial production depends primarily on the specialization of the regions. Thus, in the eight regions of Ukraine (Donetsk, Dnipropetrovsk, Zaporizhzhia, Ivano-Frankivsk, Luhansk, Mykolaiv, Rivne regions), the industry has a resource-raw material direction. In them the products of the fuel industry, iron and nonferrous metal industry, electric power industry occupies more than $50 \%$ of industrial production, and their share in the industry of Ukraine amounts to $60 \%$ (Semenov, Protsenko, 2009; Regions of Ukraine, 2016, 2017). At the same time, the regional structure of the industry is outdated. So, in the list of industries, hightech industries are not singled out.

The index analysis of the economic components of regional economic development makes it possible to draw the following conclusions. During 2010-2016, the indexes of the gross regional product have a positive dynamic. Growth of the GRP (gross regional product) takes place in all regions, except Donetsk and Luhansk, due to the temporary occupation of a part of these territories. At the same time, the decreasing of the GRP occurs in 2013 in the Zakarpattia, Zaporizhzhia, and Kyiv regions. This becomes evident in calculating the growth rates of this index (Zakarpattia - $(-0,01869)$, Zaporizhzhia - $(-0,86817)$, Kyiv - $(-1,05077))$. In addition, during this period, the growth rates on the whole territory of Ukraine are falling, which can be related to the political situation in the country during this period. However, in subsequent years, we can observe the increase in growth rates in most regions in comparison with the previous years.

The calculation of the GRP share in GDP (gross domestic product) shows that the largest significant share has Dnipropetrovsk region (2010 - 10.76\%; 2016 - 10.25\%), Donetsk until 2014 (2010 - 11.95\%, $2016-5.76 \%)$ and the Kyiv city, which has the largest share in GDP (2010 - 18.22\%; 2016 - 23.44\%). Also, Kharkiv, Kyiv, Luhansk, Lviv, Odesa, and Poltava regions have a significant percentage. The smallest share of GRP in GDP - Chernivtsi (2010 - 0.92\%, 2016 - 0.89\%), Ternopil (2010 - 1.18\%, 2016 $1.30 \%)$, Zakarpattia (2010 - 1.42\%, $2016-1.36 \%)$, and Volyn (2010 - 1.34\%, 2016 - 1.35\%) regions (Regions of Ukraine, 2016; Geits, Oleksandrova, Bazhal, 2007).

A negative trend with long-term consequences is the irregular distribution of investments between regions 
and the decrease of capital investment index over the past five years. For the period of 2010-2018, absolute capital investments increased from 189,061 million $\mathrm{UAH}$ to 219,420 million $\mathrm{UAH}$, that is $116.05 \%$, but the growth rates of investments in 2012-2013 are negative, respectively $-8.56 \%$ and $12.19 \%$. From 2014 , they gain positive values but almost do not exceed the growth rates in 2010-2012 (Semenov, 2006). Among the regions under this index in 2016, Kyiv and Dnipropetrovsk regions (33,169.0 million UAH) gained the lead and, among the cities, Kyiv gained the lead $(106,295.5$ million UAH); the lowest index was in Chernivtsi region (2,668.8 million UAH). The difference between them was decreased, respectively, by $12.5,12.4$, and 39.8 times. This is an objective basis for further disproportions in the economic development of the regions. Capital investment indices were the lowest in Donetsk (44.0\%) and Luhansk (39.2\%) regions where a military operation is taking place. This index was higher in Khmelnytskyi (102.6\%), Zakarpattia (94.6\%), Volyn (89.5\%), Zaporizhzhia (89.8\%), Sumy (89.1\%), Lviv (88.5\%), Poltava and Kherson (86.1\%), Rivne (80.7\%), Cherkasy regions (80.3\%) (Regions of Ukraine, 2016, p. 191). The mentioned regions in the total volume of capital investments occupy a small part but the dynamics of investment processes in them is higher than in areas with a significant amount of investment. It would be possible to consider this as a positive moment if it was happening against the backdrop of growth, rather than the investment bust. Since 2017, volumes of investments have decreased significantly in all regions, which indicates a deterioration of the investment environment in Ukraine. The significant share of foreign investments in the structure of capital investments for the whole of Ukraine increased in 2010-2014 from $2.1 \%$ to $2.6 \%$. The highest index was in Kyiv region - 22.1\%, in Ivano-Frankivsk region it was $5.3 \%$, in Lviv $-2.0 \%$, in Rivne $-1.3 \%$, but starting from 2017, these indexes haven't almost changed, and some of them even has decreased (Regions of Ukraine, 2016).

Indexes of the and exports volume show a positive balance during the analysed period in Vinnytsia, Dnipropetrovsk, Zhytomyr, Zaporizhzhia, Kirovohrad, Mykolaiv, Poltava, Rivne, Sumy, Kherson, and Cherkasy regions.

The somewhat different situation takes place in other regions. During the analysed period, there is a domination of imports over exports in Kyiv, Lviv, Kharkiv regions and in Kyiv city. However, in the Volyn, Zakarpattia, Ivano-Frankivsk, Odesa, Ternopil, Khmelnytskyi, Chernivtsi, and Chernihiv regions, import dominated until 2013-2014. Although it is generally accepted that the domination of exports is a positive phenomenon, in this case, the cause of the change in dynamics is crisis processes in the country, which led to importers distrust. In the future, the reduction in imports has a positive impact because it stimulates national production.
The growth rates of exports and imports were negative during 2013-2015. In addition, it is important to note that in a significant number of regions, the negative import growth rates have appeared since 2012 (Volyn, Dnipropetrovsk, Donetsk, Zhytomyr, Zaporizhzhia, Ivano-Frankivsk, Mykolaiv, Rivne, Sumy, Kherson, and Chernihiv).

The index of labour productivity gains the lowest growth rates in 2013-2014 on the whole territory of Ukraine. In subsequent years takes place an increase in labour productivity.

The average standard deviation indicates how much in the mean specific values differ from their average meanings. It is a square root of the variance. The smaller the variance, the less the deviation from the average. The calculation of these indexes showed the following results.

The average value and the average standard deviation are confirmed by our preliminary conclusions about the share and volume of GRP in GDP of Ukraine and allow hereinafter dividing the regions into those with the largest share in the GRP, the average, and the smallest.

The average investment value indicates that the largest amount of investments comes to Kyiv city, Dnipropetrovsk, Kyiv, Donetsk, Lviv, Odesa, and Kharkiv regions. At the same time, the Chernivtsi, Chernihiv, Kherson, and Zakarpattia regions receive the smallest part of investments.

According to the calculated average values of exports and imports, the largest volumes of exports come from Kyiv city, Dnipropetrovsk, Donetsk, and Zaporizhzhia regions. At the same regions, as well as in the Kyiv region, the volume of imports is also the largest one. However, there is observed the imports domination in Kyiv city and in Kyiv region, whereas in other regions, the domination of exports is observed.

The calculated dispersion values for all indexes in all regions indicate significant deviations from the average values. This may be a demonstration of disproportion in the dynamics of the economic components of Ukraine regional development. Economic phenomena in the country are not stable and predictable.

The industrialized regions are investment attractive, as there is a direct dependence between the volumes of industrial production, capital investments, and foreign investments. In such regions as Dnipropetrovsk (16.5\%), Donetsk (12.4\%), Zaporizhzhia (6.6\%), Poltava (5.6\%), Kharkiv (4.9\%), and Kyiv city (24.6\%) concentrates $70.6 \%$ of industry products and services. In the named regions and Kyiv city, the capital investments are accounted for $51.1 \%$, including foreign one (Regions of Ukraine, 2016, p. 190, 205). Investments, including foreign one, are invested mainly in leading industrial sectors, while other industries are on the down-grade and not receive adequate funding.

The lack of strategic foreign investors and the weak investment activity of Ukrainian enterprises are connected with unfavourable investment climate, 
mechanism incompleteness of the capital market of the national and regional levels, and the inconsistency of the state investment regional policy. In addition, the regional economic development is constrained by the low level of regional competition, the deepening of regional disproportion, the competition for foreign investments between the state and regions, as well as taking into account by investors not only the rational distribution of production but also the level of development of market infrastructure, possibility of the lobbying of regions interests in government agencies.

The disproportion in regional economic development can be overcome with the help of structural changes that are most needed for regions with the domination of agricultural and resources industries. They need government support for the process of structural changes, the solution of social problems, and the development of new industries and spheres. In the process of decentralization, these problems are also solved by incorporating local development mechanisms and realizing the economic interests of regions and communities.

International business activity of the regions also contains significant disproportions. The part of such regions as Dnipropetrovsk, Donetsk, Zaporizhzhia, and Kyiv in all Ukrainian exports is more than $50 \%$. At the same time, the structure of exports is dominated by goods with a low share of added value: ore, metal products, products of the chemical industry, cereals. These regions also account for a larger share of imports. While the share of such regions as Zhytomyr, Kirovohrad, Rivne, Ternopil, Kherson, Khmelnytskyi, Chernivtsi, and Chernihiv amounted to less than 1\% (Regions of Ukraine, 2016, 2017). The result of these processes is the leadership of industrialized regions of innovative development since they are concentrated by the scientific institutions, highly-qualified personnel, developed industrial and non-production infrastructure, institutes of development and support of entrepreneurship. As a result, a potential basis is created for effective development policy of these regions, while in the most regions, even under decentralization, it is under challenge, as previous development has conserved problems that need to be resolved before starting the mechanism of modern economic development of these regions.

\section{Conclusions}

Equalization of the regional economic development involves the creation of a favourable investment environment in the regions, as the current trends of regional development lead to the fact that regions and other territorial entities become independent gamblers near the state in the global economic space. Some regions are actively involved in international economic relations. The regions of Ukraine are not developed to such level, and the disproportions that exist between the developments of the regions do not contribute to the dynamics of their economies. The low competitiveness of most regions of Ukraine leads to the fact that even competitive regions do not provide high rates of development. Decentralization processes that began after the adoption of relevant laws in 2015 cannot solve all the accumulated problems. The financial situation in the regions is also characterized by significant disproportions and since the process of decentralization is concentrated primarily on financial decentralization, in the final analysis, the unevenness and disproportionality of regional economic development may be increased, especially in the first stages of a real decentralization of economic power. Therefore, it is necessary to consider all components of economic development in the process of economic power decentralization from economic to institutional, which will provide a synergistic effect and provide the appropriate development dynamics for the national and regional economy.

\section{References:}

Derzhavna sluzhba statystyky Ukrainy (2016). Rehiony Ukrayiny [Regions of Ukraine]. Kyiv: State Standard of Ukraine. Retrieved from: http://www.ukrstat.gov.ua/ (accessed 12 May 2019).

Derzhavna sluzhba statystyky Ukrainy (2017). Rehiony Ukrayiny [Regions of Ukraine]. Kyiv: State Standard of Ukraine. Retrieved from: http://www.ukrstat.gov.ua/ (accessed 12 April 2019).

Filippenko, A. S. (2006). Ekonomichnyy rozvytok suchasnoyi tsyvilizatsiyi [Economic development of modern civilization]. Kyiv: Znannia Ukrainy. (in Ukrainian)

Galchynskyi, A. S. (2012). Ekonomichnyy rozvytok: metodolohiya onovlenoyi paradyhmy [Economic development: Methodology of renewed paradigm]. Economy of Ukraine, 5, 4-17.

Geits, V. M., Oleksandrova, V. P., Bazhal, Yu. M. (2007). Stratehichni vyklyky 21 stolittya suspilstvu ta ekonomitsi Ukrayiny V.1. Ekonomika znan - modernizatsiynyy proekt Ukrayiny [Strategic challenges of the 21st century to society and economy of Ukraine. V.1. Knowledge-based economy - a modernization project of Ukraine]. Kyiv: Phoenix. (in Ukrainian)

Geiets, V. M., Mazaraki, A. A. (ed.) (2008). Priorytety natsionalnoho ekonomichnoho rozvytku v konteksti hlobalizatsiynykh vyklykiv [Priorities of national economic development in context of globalization challenges]. Kyiv: KNTEU. (in Ukrainian)

Held, D., McGrew, A., Goldblatt, D., Perraton, J. (2000). Global Transformations: Politics, Economics and Culture. In: Pierson C., Tormey S. (Eds.) Politics at the Edge. Political Studies Association Yearbook Series. Palgrave Macmillan, London. 
Maier, D., Rauch, D. E., Filipenko, A. S. (2003). Osnovni problemy ekonomiky rozvytku [Main problems of development economy]. Kyiv: Lybid. (in Ukrainian)

Prokofieva, G. S. (2018). Osoblyvosti mekhanizmu stiykoho ekonomichnoho rozvytku vumovakh detsentralizatsiyi ekonomiky [Features of the mechanism of sustainable economic development in conditions of decentralization of the economy]. Odesa National University Herald. Series economy. Volume 23, Issue 3(68), 91-96.

Semenov, V.F. (ed.) (2006). Ekolohichnyy menedzhment [Ecological management]. Kyiv: Znannia. (in Ukrainian) Semenov, V. F., Protsenko, T. O. (2009). Rehionalna ekonomika [Regional economy]. Study guide / edited by V. F. Semenov. Kyiv: MF Lesia. (in Ukrainian)

Zhalilo, Ya. A. (2013). Formuvannya modeli ekonomichnoho rozvytku Ukrayiny u pislyakryzovyy period [Formation of model of economic development of Ukraine in the post-crisis period]. Kyiv: NISS. (in Ukrainian)

Zhalilo, Ya. A., Makarov, G. V., Danylyak, O. O., Rudenko, A. F. (2018). Detsentralizatsiya vlady: yak zberehty uspishnist v umovakh vyklykiv? [Decentralization of power: how to maintain success in a challenging environment?]. Kyiv: NISS. (in Ukrainian)

Voluntary association of territorial communities: Law of Ukraine dated on February 5, 2015, No. 157-VIII. Retrieved from: https://zakon.rada.gov.ua/laws/show/157-19 (accessed 05 April 2019). 